\title{
Growing fruit trees, medicinal plants and spices in the state of Goa, India
}

\author{
I. M. Madaleno \\ Portuguese Tropical Research Institute, Portugal
}

\begin{abstract}
Fruit trees, spices and medicinal plant species are essential components of the home gardens in India. Traditional medicinal knowledge, in particular Ayurvedic medicine, are frequently adopted by urban gardeners and urban residents, in general. This contribution explores the multiple functions of urban agriculture in the Indian state of Goa. The research hypothesis is that the adoption of organic agriculture by the urban households contributes for environmental sustainability and increases the resilience of tropical humid coastal cities, to climate change. The main objective is to report on the role of the ethno-medicines and food gardened in the front- and backyards of coastal cities and touristic agglomerations. This paper uses a comparative method that puts localism at the service of abstraction. Time and space are both part of the analysis, because the urban settlements of Goa, and several Malabar Coast Indian places, were colonised by Portugal (1510-1961). Archival research permits us to cross-examine plant consumption through times, and previous investigation conducted in Kochi allows comparisons within India. Results show that Indian urban farming systems are adapted to ancient cultural and religious beliefs that European presence did not change completely. Traditional medicinal knowledge is an essential alternative for lowincome urban households and is an integrative part of Indian culture, for healing is a holistic practise in India. The persistent cultivation of kitchen gardens, associated to the option for less dense urban tissues than elsewhere in India, permitted the survival of several low-lying coastal settlements of Goa to the monsoon floods.
\end{abstract}

Keywords: sustainable cities, coastal agglomerations, ethno-medicines. 


\section{Introduction}

The Indo-Portuguese period of Goa lasted four hundred and fifty-one years. Old Goa (Velha Goa) was the first most important settlement of the Portuguese Indian State (Estado da Índia) and became the capital city of a vast territory, extended from the Cape of Good Hope (now in the Republic of South Africa) and Macau (China). The head of the Portuguese Indian State was definitely settled at Panaji (Panjim), in 1843. Whereas the colonisation of most part of these overseas territories was littoral, based on fortresses built in geopolitical locations intended to favour and protect European navigation along the oriental coast of Africa or throughout the South and Southeast Asia; Goa, located between $14^{\circ} 53^{\prime} \mathrm{N}$ and $15^{\circ} 47^{\prime} \mathrm{N}$ of the Equator, was an effectively occupied territory, without interruption from the year (1510) the governor Afonso de Albuquerque conquered the area and led the colonisation process, to the moment India (1961) invaded Goa [1-3]. The exceptions were a three months blockade conducted by an Anglo-Dutch fleet, in 1622, and a series of annual Dutch blockades that occurred between the years 1636 and 1663 [4].

The state of Goa is currently the smallest of India, situated along a stretch of the western coast called Konkan, where the people speak Konkani [1]. The climate is tropical humid, and the monsoon lasts from June to September, whilst the temperatures range from $24^{\circ}$ to $28^{\circ} \mathrm{C}$ [2]. The maximum width of the state is $60 \mathrm{~km}$, and therefore most cities are either coastal or located close to the seashores. Goa has a good number of beaches but also rich forests inland [1,2]. The fieldwork took place during dry season and included the northern beach settlement of Candolim, where $42 \%$ of the interviews were conducted; followed by the capital city of Panaji, located in the central island of Tiswadi, where Portuguese colonization started, with $34 \%$ of the informants; through the trade post of Mapusa, in Bardez, where $12 \%$ of the interviews were gathered; then came the old southern commercial hub of Margão, with $6 \%$ of the informants, in Salcete; to finalise in a spice farm of Ponda district, situated further away from the sea, to the east of Panaji [5].

The survey totalled fifty interviews. The urban agglomerations investigated during 2014 fieldwork totalled seven. All of them display distinctive marks of Portuguese colonisation [3], both in architecture (Fig. 1) and urban planning, as in gardening (Fig. 2). This unique cultural identity gave Goa its own personality, within the Indian subcontinent, exacerbated by the fact that it was (together with Daman and Diu, located to the North of India) the territory where the impact and duration of the Portuguese presence lasted for over four centuries. The main objective of this research paper is to report on the role of the ethno-medicines and food gardened in the state of Goa, predominantly in coastal cities. Crossexamination of early Portuguese colonisation preferences ( $16^{\text {th }}$ and $17^{\text {th }}$ centuries) and the $21^{\text {st }}$ century fruits, spices and medicinal flora gardened, traded and applied by healers in the researched space, will be a specific objective. The research hypothesis is: the adoption of organic agriculture by the urban households contributes for their environmental sustainability and increases the resilience of tropical humid coastal cities, to climate change. 


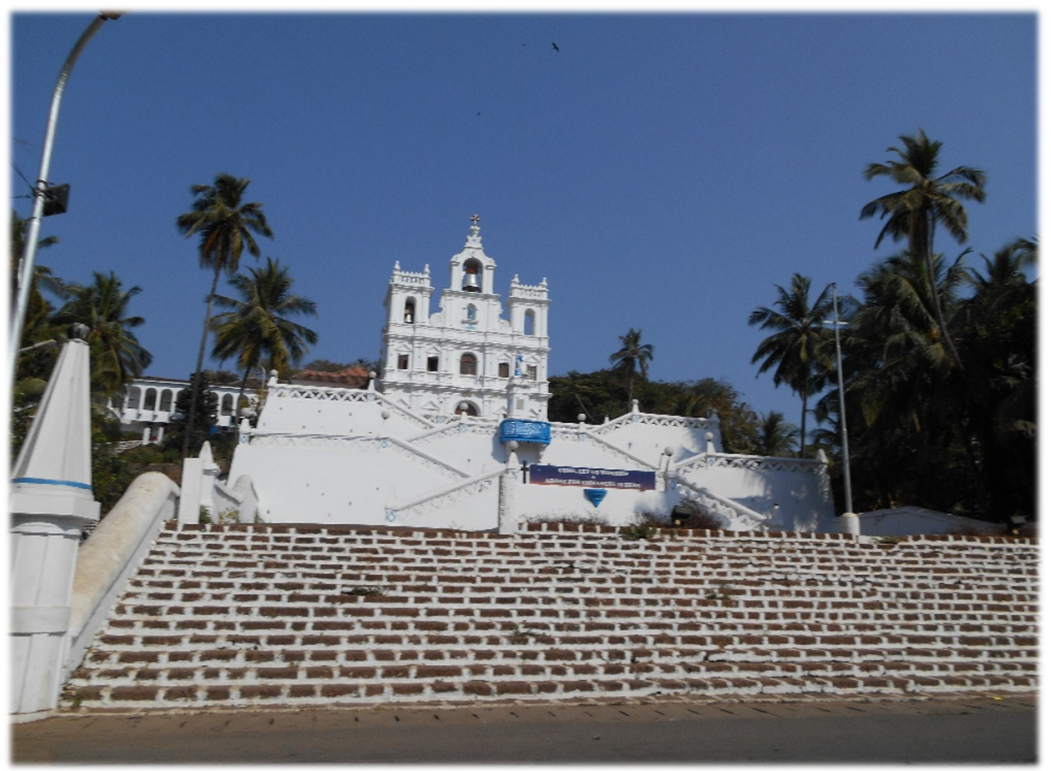

Figure 1: Church of Panaji, a typical example of a Portuguese religious temple in India. Source: photo by the author, 2014.

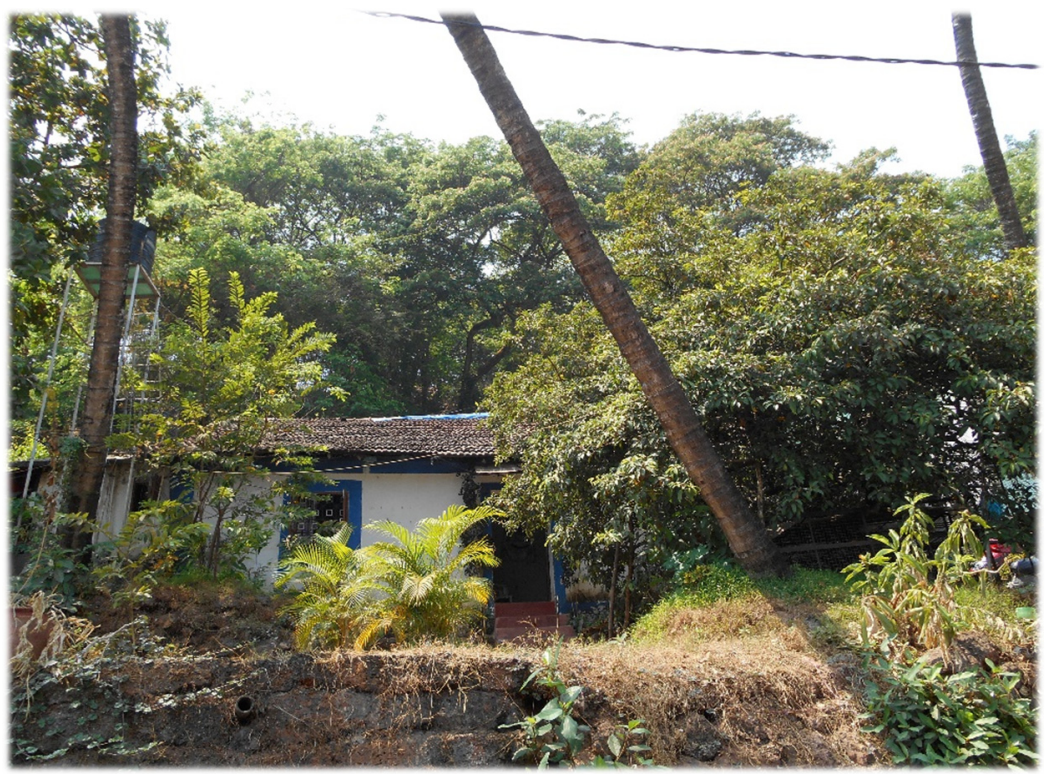

Figure 2: Garden of Panaji, displaying the chicoo tree to the right side of the house, a species introduced from America during the Portuguese colonization. Source: photo by the author, 2014. 


\section{Materials and methods}

The research process was twofold:

1. Archival examination of manuscripts written about plant species used as food and medicine, in the early years of Portuguese colonization, was the first step;

2. Surveys containing standard questions about the medicinal flora consumed in Goa constituted the next phase.

Regarding the historical data gathered, the focus in this paper will be the first herbal published in India, in 1563, by the Portuguese-Jewish doctor Garcia d'Orta, who lived in Goa most of his adult life [6]. The second manuscript under examination is authored by Manuel Godinho Erédia, available in 1612, an herbalist and cartographer born in Malacca in 1560, which family moved to India when he was thirteen years old. He lived in the Indian subcontinent for about thirty years, namely in Goa and Kochi [7]. Their findings contained a total of one hundred and thirty-four (134) different plant species, illustrated in Erédia's Codex.

As to the second phase of the research process, the 2014 surveys conducted at the service of the Portuguese Tropical Research Institute (IICT) used sample questionnaires, similar to the ones applied in previous Latin American fieldwork [8-9]; they are equal to the ones used in the case study of Kochi, located in the Indian Kerala state, gathered in 2013 [10], and those applied in Malacca, Malaysia, later in the same year [11]. Three focus groups were involved in the process:

1) The urban gardeners and spice farmers who grew medicinal flora were twenty-six ( $52 \%$ of the interviews);

2) The fruit, spice and herb traders, including the plant pharmacists totalled twenty-two (44\%);

3) The plant therapists, herbalists and traditional healers were two (4\%).

Data collected during the 2014 survey used qualitative methodology [12], in line with previous investigations. Information gathered includes a photographic record of the local flora so as to permit the design of an illustrated plant catalogue. In order to identify the plants used as food and medicine, which totalled one hundred and fifty (150), the characterization and the scientific denomination were obtained in the publications of Sahni [13], Prendergast et al. [14], Mendes Ferrão [15], and Proença da Cunha and Roque [16]. The taxonomy was updated using the Missouri Botanical Garden database, available online [17].

\section{Results}

The sustainable agriculture movement is concerned with the environment, considering organic farms as an approximation to wild nature [18]. Whenever organic cultivation is continually practiced within the urban tissue or in peri-urban areas, the phenomenon is designated urban gardening or peri-urban farming, respectively $[19,20]$. In India, herbal medicine is a millenary practise mostly associated with Ayurvedic therapeutics. In the state of Goa gardens display a diverse number of spices, legumes, medicinal herbs and fruit trees. Chemical-free 
urban plots dominate, because Hinduism and Ayurvedic medicine reject such un-natural consumption, both in food as in healing plants.

Table 1 presents the top-ranking medicinal plants, fruits and spices consumed in Goa, and cross-examines the modes of preparation and the affections they heal these days, with the diseases the same species cured in Renaissance times. Results show that cow manure is the preferred method of fertilization in the twenty-six gardens explored. Organic input in front and backyards corresponds to $57.7 \%$. Chemical fertilization was applied by three gardeners $(11.5 \%)$, all of them Christians. Even so, eight urban cultivators didn't fertilise their front and backyards $(30.8 \%)$, because they considered the urban soil didn't require such care. Another important result from the survey was that in fifteen houses of the first focus group interviewed (57.7\%), the urban gardeners, possessed wells and used to regularly irrigate the spices, medicinal herbs and fruit trees they grew.

The top-ranking plant species consumed in Goa is tulsi or Krishna tulsi, used in Hinduism for prayer; besides having the virtue of blessing the house and the family, the Lamiaceae cures respiratory ailments, such as cough and colds, and is preferred to heal children. Tulsi wasn't described by any of the Renaissance authors examined, but it is by far the most important plant gardened in India's front and backyards, even in pots, in tiny gardens, as research conducted in Kochi evidenced [10], and also among the Indian community established in Malacca, Malaysia [11]. Am or mango, in Konkani, follows suit, another native plant species that has been expanded all over the tropical world. Mango bark is consumed against diabetes in Goa, the same application found in Belen, Brazil, in 1998 $[8,9]$.

During Renaissance, Indians used the leaf of mango trees against dysentery, a medicinal application that didn't endure in India nor in any Latin American country investigated at the service of the IICT (Brazil, Mexico, Peru, Chile, Argentina, Uruguay, Costa Rica and Cuba). Papaya trees, chilli (named Portuguese Peri-Peri in Goa), the pineapple and the chicoo tree were introduced in India by the Portuguese [15]. In fact, if the pineapple and the papaya were illustrated and described in the 1612 manuscript of Erédia [7] in the 1563 Orta's Codex there was no mention to these fruit species [6]. American fruits and spices were easily transported from Brazil, because the trade winds frequently obliged ships to navigate deep into south-western Atlantic waters. Extra cargo was then added as the ships navigated practically empty from Lisbon to Goa, where they were loaded of spices.

Navigation used the Cape of Good Hope route and gave way to paradoxical food and cooking habits, such as current preference for Capsicum annuum in Goa (the American chilli), in detriment of native Piper nigrum. Results from the 2013 Kochi survey also reported this phenomenon; in fact, chilli presented the $5^{\text {th }}$ post on the list of top-ranking consumptions and pepper the $9^{\text {th }}[10]$. Black pepper was the most relevant spice for the Europeans during Renaissance, as it soon became in Brazil, as found in Belen $[9,21]$. Truth is the $19^{\text {th }}$ century Japanese immigrants to the Amazon Region were the main farmers of the Indian spice; however the preference preceded the cultivation, because maritime trade of spices brought it to 
Table 1: Evolution in consumption of top-ranking plant species in Goa.

\begin{tabular}{|c|c|c|c|c|}
\hline $\begin{array}{c}\text { Vernacular } \\
\text { name } \\
\text { (Konkani) }\end{array}$ & Botanical name & $\begin{array}{l}\text { Applications during } \\
\text { Renaissance }\end{array}$ & $\begin{array}{l}\text { Current mode of } \\
\text { preparation }\end{array}$ & No. \\
\hline 1. Tulsi & $\begin{array}{l}\text { Ocimum sanctum } \mathrm{L} . \\
\text { LAMIACEAE }\end{array}$ & Not recorded & $\begin{array}{c}\text { Infusion/concoction of } \\
\text { the leaf or flower against } \\
\text { cough, colds, asthma. } \\
\text { The oil with honey } \\
\text { purifies the blood and } \\
\text { resolves kidney } \\
\text { infections }\end{array}$ & 26 \\
\hline 2. Am Mango & $\begin{array}{l}\text { Mangifera indica } \mathrm{L} \text {. } \\
\text { ANACARDIACEAE }\end{array}$ & $\begin{array}{l}\text { The leaf cured } \\
\text { dysentery. The fruit of } \\
\text { the Indian species was } \\
\text { eaten, and expelled } \\
\text { intestinal worms }\end{array}$ & $\begin{array}{c}\text { Cultivated in the } \\
\text { gardens. The ripe fruit is } \\
\text { eaten raw. The green } \\
\text { fruit is cooked in curry. } \\
\text { The bark is used against } \\
\text { diabetes together with } \\
\text { others }\end{array}$ & 19 \\
\hline 3. Papaya & $\begin{array}{l}\text { Carica papaya } \mathrm{L} . \\
\text { CARICACEAE }\end{array}$ & $\begin{array}{c}\text { Fruit tree introduced by } \\
\text { the Portuguese }\end{array}$ & $\begin{array}{c}\text { Fruit eaten raw for its } \\
\text { digestive powers }\end{array}$ & 15 \\
\hline 4. Aloe & $\begin{array}{c}\text { Aloe vera }(\mathrm{L} .) \text { Burm f. } \\
\text { XANTHO- } \\
\text { RRHOEACEAE }\end{array}$ & $\begin{array}{l}\text { Sap was considered } \\
\text { strong diuretic and used } \\
\text { to purge, consumed } \\
\text { against kidney and } \\
\text { bladder infections }\end{array}$ & $\begin{array}{l}\text { Sap applied against skin } \\
\text { rashes, burns, wounds. } \\
\text { Ingested for heart } \\
\text { diseases }\end{array}$ & 14 \\
\hline $\begin{array}{l}\text { 5. Nutmeg, } \\
\text { Mace }\end{array}$ & $\begin{array}{l}\text { Myristica fragrans } \\
\text { Houtt. } \\
\text { MYRISTICACEAE }\end{array}$ & $\begin{array}{l}\text { Spice. The nut chewed } \\
\text { prevented halitosis. } \\
\text { Anti-dysenteric, the oil } \\
\text { was calming balm }\end{array}$ & $\begin{array}{l}\text { Spice. The nut resolves } \\
\text { diarrhoea, joint pains, } \\
\text { and rheumatism }\end{array}$ & 14 \\
\hline 6. Coconut & $\begin{array}{l}\text { Cocos nucifera } \mathrm{L} . \\
\text { ARECACEAE }\end{array}$ & $\begin{array}{c}\text { Skin application as } \\
\text { anti-septic. Coconut } \\
\text { water was digestive and } \\
\text { used to purge. The pulp } \\
\text { was anti-venom } \\
\end{array}$ & $\begin{array}{l}\text { Skin application as } \\
\text { anti-septic }\end{array}$ & 13 \\
\hline 7. Curry & $\begin{array}{l}\text { Murraya koenigii (L.) } \\
\text { Spreng. } \\
\text { RUTACEAE }\end{array}$ & No record & \begin{tabular}{|} 
The oil is rubbed to \\
strengthen the gums. \\
Spice tree grown in the \\
gardens. The leaf is \\
chewed to lower blood \\
pressure and against \\
diabetes
\end{tabular} & 11 \\
\hline $\begin{array}{l}\text { 8. Payam, } \\
\text { Banana, } \\
\text { Indian Fig } \\
\text { Tree }\end{array}$ & $\begin{array}{l}\text { Musa paradisiaca } \mathrm{L} . \\
\text { MUSACEAE }\end{array}$ & $\begin{array}{c}\text { The fruit was } \\
\text { considered diuretic, } \\
\text { aphrodisiac and was } \\
\text { cooked in wine and } \\
\text { cinnamon. The latex of } \\
\text { the tree was calming } \\
\text { balm }\end{array}$ & $\begin{array}{l}\text { Cultivated in the gardens } \\
\text { and consumed in Goa. } \\
\text { The fruit is also fried in } \\
\text { chips and the young leaf } \\
\text { wrapped in betel to } \\
\text { strengthen the gums and } \\
\text { teeth }\end{array}$ & 11 \\
\hline 9. Ginger & $\begin{array}{l}\text { Zingiber officinale } \\
\text { Roscoe } \\
\text { ZINGIBERACEAE }\end{array}$ & $\begin{array}{l}\text { Anti-fever, anti-flu, } \\
\text { spice and good } \\
\text { appetiser }\end{array}$ & \begin{tabular}{|c|} 
Root consumed in \\
relaxing concoction. \\
Also against cough, \\
colds, indigestion, \\
arthritis, circulatory \\
problems \\
\end{tabular} & 11 \\
\hline
\end{tabular}


Table 1: Continued.

\begin{tabular}{|c|c|c|c|c|}
\hline $\begin{array}{l}\text { Vernacular } \\
\text { name } \\
\text { (Konkani) }\end{array}$ & Botanical name & $\begin{array}{l}\text { Applications during } \\
\text { Renaissance }\end{array}$ & $\begin{array}{l}\text { Current mode of } \\
\text { preparation }\end{array}$ & No. \\
\hline $\begin{array}{l}\text { 10. Portuguese } \\
\text { Peri-peri }\end{array}$ & $\begin{array}{l}\text { Capsicum anпиит } \mathrm{L} . \\
\text { SOLANACEAE }\end{array}$ & $\begin{array}{l}\text { American spice } \\
\text { introduced by the } \\
\text { Portuguese }\end{array}$ & The fruit is spice & 10 \\
\hline 11. Cardamom & $\begin{array}{l}\text { Elettaria cardamomum } \\
\text { (L.) Maton var. major } \\
\text { and minus } \\
\text { ZINGIBERACEAE }\end{array}$ & $\begin{array}{c}\text { Spice. Chewed } \\
\text { prevented halitosis, } \\
\text { sometimes combined } \\
\text { with Areca nut }\end{array}$ & $\begin{array}{l}\text { Spice. Also ingested in } \\
\text { infusion for weight loss. } \\
\text { Concoction of the seed } \\
\text { improves the memory } \\
\text { and cures depression } \\
\end{array}$ & 9 \\
\hline 12. Pineapple & $\begin{array}{l}\text { Ananas comosus (L.) } \\
\text { Merr. } \\
\text { BROMELIACEAE }\end{array}$ & \begin{tabular}{|c|} 
Digestive. Excessive \\
consumption provoked \\
fever and indigestion \\
\end{tabular} & $\begin{array}{c}\text { Digestive fruit cultivated } \\
\text { in the gardens }\end{array}$ & 9 \\
\hline $\begin{array}{l}\text { 13. Haldi, } \\
\text { Turmeric }\end{array}$ & $\begin{array}{l}\text { Curcuma longa } \mathrm{L} \text {. } \\
\text { ZINGIBERACEAE }\end{array}$ & $\begin{array}{c}\text { Root is anti-septic, } \\
\text { spice and cured scabies } \\
\text { together with coconut } \\
\text { oil }\end{array}$ & $\begin{array}{l}\text { Spice. The root applied } \\
\text { to the skin is anti-septic. } \\
\text { Anti-inflammatory, } \\
\text { analgesic and anti- } \\
\text { cough, ingested with } \\
\text { honey and lime }\end{array}$ & 9 \\
\hline 14. Chicoo & $\begin{array}{c}\text { Manilkara zapota }(\mathrm{L} .) \mathrm{P} . \\
\text { Royen } \\
\text { SAPOTACEAE } \\
\end{array}$ & $\begin{array}{c}\text { American fruit } \\
\text { introduced by the } \\
\text { Portuguese }\end{array}$ & $\begin{array}{c}\text { Fruit tree cultivated in } \\
\text { the gardens, very } \\
\text { nutritious fruit }\end{array}$ & 9 \\
\hline $\begin{array}{l}\text { 15. Carim } \\
\text { Watermelon }\end{array}$ & $\begin{array}{c}\text { Citrullus lanatus } \\
\text { (Thunb.) } \\
\text { Matsum and Nakai } \\
\text { CUCURBITACEAE }\end{array}$ & \begin{tabular}{|c|} 
Diuretic, anti-fever. \\
Nutraceutical eaten \\
against liver and kidney \\
problems
\end{tabular} & $\begin{array}{l}\text { The fruit is appreciated } \\
\text { and the seeds are } \\
\text { consumed toasted }\end{array}$ & 8 \\
\hline $\begin{array}{l}\text { 16. Lemon } \\
\text { grass }\end{array}$ & $\begin{array}{l}\text { Cymbopogon citratus } \\
\text { (DC.) Stapf } \\
\text { POACEAE }\end{array}$ & Not recorded & $\begin{array}{l}\text { Infusion of the leaf } \\
\text { consumed against cough } \\
\text { and colds. Oil drops on } \\
\text { the skin against acne. In } \\
\text { water for depression }\end{array}$ & 7 \\
\hline
\end{tabular}

Source: Survey by the author.

America, either en route to Europe or in separate fares. The spice route established by the Portuguese fomented the expansion of medicinal flora and spices all around the world and promoted the early botanical trade of exotic flora from Asia to America and back to Europe [22].

Nevertheless, the analysis of Table 1 shows that native plants are favoured in Goa, including other spices, namely cardamom, curry, turmeric, and ginger. Moreover several Indian spices and medicinal plants kept similar therapeutic uses to the ones reported by early herbalists and plant doctors $[6,7]$, as in the case of nutmeg and mace, ginger, Indian turmeric or the American pineapple, a fruit frequently gardened in Goa. It is the case with the Pacific coconut tree too, that is sometimes considered Indian native [7, 15]. The result that stands out is the enormous diversity of the home gardens of Goa, in line with previous research conducted in Brazil, in locations where Portuguese colonisation lasted over three hundred years, as is the case of Belen and St. Louis [8, 9, 19, 21, 23].

Biodiversity within the state of Goa reached one-hundred and fifty taxa (150) and, therefore, the garden flora far overcame the eighty-eight plant species 
registered in Kochi, in a similar sample of fifty interviews. Even though many species were gathered in trading posts, the fruit trees dominated in both sites, about $39.3 \%$ in Goa; the medicinal flora followed with $33.9 \%$ in the Konkan; spices had a percentage of $17.9 \%$; and vegetables and staples presented $8.9 \%$ within the state of Goa. Regarding the plants gardened, their purpose was the self-consumption, restricted to the extended household, as is normal in Indian culture, because parents usually continue living in the whereabouts of their adult offspring.

The similarity of results obtained in the surveys conducted in the Kerala state city of Kochi, in 2013, and in the seven settlements explored in Goa, in 2014, fuels the hypothesis that gardening in India, at least in locations colonised by the Portuguese during Renaissance, might be associated to cooking and healing traditions practised within the households and transmitted through generations. Kitchen gardening should be the tag of this specific form of urban agriculture. Our hope is that further research in coastal fortresses and trading posts might be developed, in the future, favouring port cities that had a past of European colonisation, in order to confirm or infirm the hypothesis.

\section{Discussion}

Assessments made by Rodrigues dos Santos and Mendiratta about Pedro Barreto de Resende's images ( $16^{\text {th }}$ century), as their surveys on the iconographic work of Manuel Godinho de Erédia, allow informed analysis about the urban and peri-urban areas existent within the walls of the city of Goa, during Renaissance. The emphasis should go to the extension of the rice pads and areca nut palm trees [24], that covered the extramuros (outside the walls) rural realm, in the central island of Tiswadi. In our days rice paddies no longer dominate the island, as the urban tissue is considerably more extensive, because of the city of Goa (now Old Goa), but also on account of the new capital city Panaji, and their satellite settlements. These urban and peri-urban areas are dominated by the horizontality of the buildings, of which the house in Fig. 2 (quite similar to a typical house of southern Portugal) constitutes a staggering example.

However, the areca palms still lay alongside the rivers, and particularly along the seashores (Fig. 3), most vigorously on the beaches, in Tiswadi as in Bardez $(\mathrm{N})$ and Salcete (S), giving evidence of the importance of this long sought medicinal nut, that both marvelled and distressed the herbal doctor Garcia d'Orta [6]. In fact, Areca catech $u$ L. was consumed in 1563 to strengthen the gums and against halitosis. Erédia wrote about the virtue of the leaf of this palm tree to cure haemorrhages, particularly sought after by women [7]. The Areca nut was also used to purge, a common practise in medicine, those days, yet an application that endured to present. Consumed wrapped in betel leaf (Piper betle L.) with camphor, khat (Catha edulis Forssk.), aloe and amber, in narcotic mixture to preserve the teeth, it gave Orta the certainty that the mouth of the Indians, both female and male, was always occupied and full with coloured saliva, quite repulsive. Fortunately the mixture is not so popular in present time, except for a group of faithful consumers. 


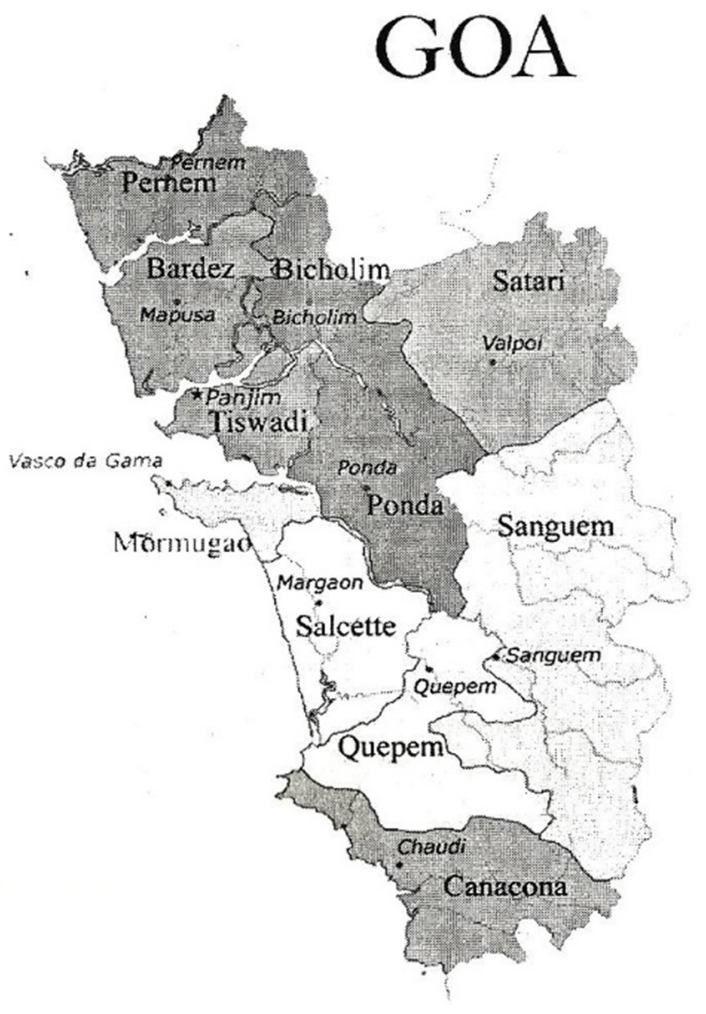

Figure 3: The State of Goa and the three islands investigated: Bardez, Tiswadi and Salcette. Source: Brito [2].

The set of Pedro Barreto de Resende's images investigated in 2011 [24], as the well-documented cartographic analysis of the geographer Raquel Soeiro de Brito, in 1966 [2], to finalise with the photographic record gathered at the service of the IICT, in 2014, prove that the total area of the state of Goa $\left(3611 \mathrm{~km}^{2}\right)$ has not greatly changed over the length of five hundred years. The coast line remains practically unaffected, in spite of the dominance of lowlands in the islands, giving evidence that Goa survived the monsoons and frequent flooding. We argue that the persistence of urban gardening and peri-urban farming as the option for the maintenance of areca nut forests along the seashores had a positive effect on Goa. Gardens are spaces of infiltration that favour the hydrological cycle and regulate the temperature.

Annual rainfall ranges from 2,400 and 3,000 mm annually [2], but the soil, the water and forest management have been wisely exploited and developed, providing evidence that the option for horizontality in construction as well as the persistent cultivation of spices, medicinal plants and fruit trees within the city is vital for climate change mitigation. Additionally, urban agriculture contributes for food and health sufficiency [25], giving lower-income households' better quality of life. Both the literature examined and data gathered during fieldwork confirm 
the research hypothesis that the adoption of organic agriculture by the urban households contributes for their environmental sustainability and increases the resilience of tropical humid coastal cities, to climate change.

\section{References}

[1] Pinho, V., Snapshots of Indo-Portuguese History, Vasco Pinho Editor: Panaji, 2007.

[2] Brito, R.S. de, Goa e as Praças do Norte. Junta de Investigações do Ultramar: Lisbon, 1966.

[3] Barreto Xavier, A., A Invenção de Goa. Poder Imperial e Conversões Culturais nos séculos XVI e XVII. Imprensa de Ciências Sociais: Lisbon, 2008.

[4] Murteira, A., The English and Dutch against the Carreira da Índia in the West Indian Ocean, 1621-1623. Oriente 19, pp. 3-26, 2008.

[5] Madaleno, I.M. Traditional Medicinal Knowledge in Goa, India. Tropentag 2014. Prague, pp. 1-4. www.tropentag.de/abstracts/full/10.pdf/82.pdf

[6] Orta, G. d', Colóquios dos simples e drogas e cousas medicinais da India. Academia das Ciências de Lisboa: Lisbon, 1963 (reedited from the imprint of Johannes of Endem, Goa, 10th April of 1563).

[7] Everaert, J. G., Mendes Ferrão, J. E., Liberato, M. C., Suma das árvores e plantas da Índia e Intra Ganges. Comissão Nacional para a Comemoração dos Descobrimentos Portugueses: Lisbon, 2001.

[8] Madaleno, I.M., Organic Cultivation and Use of Medicinal Plants in Latin America. Pharmacognosy Communications, 2(4), pp. 34-51, 2012.

[9] Madaleno, I.M., Estudo Etnogeográfico de Plantas Medicinais da América Latina. Alêtheia Editores: Lisbon, 2013.

[10] Madaleno, I.M., Landscapes of Health: The Kochi case-study. Sustainable City IX, ed. N. Marchettini, C.A. Brebbia, R. Pulselli, S. Bastianoni, WitPress: Southampton, pp. 1709-1720, 2014.

[11] Madaleno, I.M., Malaca: Puerto estratégico de Malasia, sus plantas medicinales, frutales y otras plantas útiles, en el inicio de la expansión marítima europea y en la actualidad. VI Jornadas de Geografía Económica Grupo de Geografía Económica de la AGE. Asociación de Geógrafos Españoles: Sevilla, pp. 364-383, 2014.

[12] Berg, B.L., Qualitative Research Methods for the Social Sciences. Pearson: New York, 2006.

[13] Sahni, K.C., The Book of Indian Trees. Bombay Natural History Society/ Oxford University Press: Oxford, 2000.

[14] Prendergast, H.D.V., Etkin, N.L., Harris, D.R. and Houghton, R.J., Plants for food and medicine. The Royal Botanic Gardens: Kew, 1998.

[15] Mendes Ferrão, J.E., Fruticultura Tropical. Espécies com frutas comestíveis. I.I.C.T.: Lisbon, 1999 to 2002 (volumes 1 to 3).

[16] Proença da Cunha, A. and Roque, O.R., Plantas Medicinais da Farmacopeia Portuguesa. Fundação Calouste Gulbenkian: Lisbon, 2011.

[17] Missoury Botanical Garden, 2015. www.tropicos.org. 
[18] Alkon, A., Paradise or pavement: the social constructions of the environment in two urban farmers' markets and their implications for environmental justice and sustainability. Local Environment 13(3), pp. 271-289, 2008.

[19] Madaleno, I.M., Cultivating our cities. Environmental Impact, ed. C. A. Brebbia \& T. Chon, Wit Press: Southampton, pp. 183-192, 2012.

[20] De Zeeuw, H. RUAF 10 years: achievements and challenges. Urban Agriculture Magazine 25, pp. 3-7, 2011.

[21] Madaleno, I.M., Urban Agriculture in Brazil: A Tale of Two Cities. Trialog, 65(2), pp. 24-27, 2000.

[22] Madaleno, I.M., Indian herbs and trees grown and traded in Cochin, in the 16th century and nowadays. Life in a Changing Urban Landscape, ed. N. Kotze,, R. Donaldson, G. Visser, University of Johannesburg/Urban Geography Commission: Johannesburg, pp. 338-346, 2014.

[23] Madaleno, I. M., Plantas da Medicina Popular de São Luís, Brasil. Boletim do Museu Paraense Emílio Goeldi. Ciências Humanas, 6(2), pp. 273-286, 2011.

[24] Rodrigues dos Santos, J. and Mendiratta, S. L. (2011) Goa, Daman and Diu as seen by Pedro Resende: A comparative analysis of his cityscapes. Oriente 20: pp. 51-62, 2011.

[25] Sage, C. Environment and Food. Routledge: Abingdon, 2011. 